\title{
ON THE DEFENCE OF AURARIAE DACICAE
}

Ovidiu Țentea

\section{Despre apărarea aurariae Dacicae}

Apărarea cadrilaterului aurifer a fost un subiect abordat de mai multe ori în literatura de specialitate, fiind tratat de obicei împreună cu tema frontierei de vest a provinciei Dacia. Cu toate acestea, informațiile de care dispunem până în acest moment sunt insuficiente sau neclare, tocmai în sectorul cuprins între castrele de la Micia şi Bologa, anume în zona Munților Apuseni.

Această discuție argumentează câteva elemente ale unui posibil model de funcționare a apărării zonei minelor aurifere. Nu am intenționat însă să realizez o analiză detaliată a întregii problematici.

Staționarea legiunii XIII Gemina la Apulum, încă din primii ani ai provinciei, pe întreaga durată a existenței acesteia, a fost pusă în legătură şi cu paza zonei aurifere, respectiv cu protejarea transportului aurului extras în Muntii Apuseni. Odată cu venirea legiunii V Macedonica în Dacia, segmentul Potaissa Apulum cuprinde două legiuni şi o ala milliaria, fapt care indică în mod special necesitatea întăririi pazei zonei aurifere. Aşadar, aducerea legiunii la Potaissa indică interesul deosebit pentru întărirea unei zone sensibile şi deosebit de importante. Amplasarea a două legiuni la o distanţă mică pentru apărarea unei zone vitale din punct de vedere strategic este un fapt cunoscut pe unele sectoare dunărene, cum ar fi Singidunum-Viminacium, Brigetio-Aquincum sau Vindobona-Carnuntum. În Dacia se poate observa o concentrare de efective militare în zona auriferă şi a graniței vestice, areal grav afectat în cursul războaielor marcomanice.

Astfel, s-a putut observa în cazul Moesiei Superior, că recrutările trupelor din anul 169 p. Chr. au avut în vedere campania din anul următor contra iazigilor. Se poate observa faptul că, de-a lungul timpului, apărarea zonelor miniere constituia o prioritate pentru Roma, în special în perioadele de criză. Deseori, în literatura de specialitate, îndeplinirea acestor sarcini a fost atribuită efectivelor legionare. Atestarea legionarilor în zonele miniere indică, mai degrabă, implicarea acestora în cadrul activităților miniere, aceştia oferind suportul economic, administrativ şi tehnic necesar. Sarcina principală a formațiunilor auxiliare era protejarea activităților miniere, a transportului metalelor prețioase şi a aprovizionării zonelor respective. Astfel se explică preponderența formațiunilor echipate cu unități de cavalerie, amplasate în proximitatea acestui areal, în fortificații situate de-a lungul unor artere rutiere, care facilitau accesul rapid în puncte importante din zona minelor de aur: Micia, Cigmău-Germisara, Ampelum, Războieni, Gilău, posibil Bologa.

Apărarea minelor de aur ale Daciei a fost legată de cea a frontierei vestice a provinciei. Astfel, un rol central l-a deținut inițial legiunea XIII Gemina, ulterior atribuțiile par să fi fost împărțite parțial cu legiunea V Macedonica. Acest fapt reiese din amplasarea legiunii din urmă, într-un moment de criză, la capătul unui important culoar rutier, care conducea spre acest areal, apoi mai departe spre frontiera vestică.

Capacitatea unor trupe staţionate în interiorul provinciei de a ajunge rapid în zona cuprinsă între castrele dintre Micia şi Bologa ar putea explica lipsa unor fortificații semnalate în acest areal. Această presupunere este condiționată, fireşte, de stadiul actual al cercetărilor.

Key words: aurariae Dacicae, legionaries, beneficiarii consularis, equestrian auxiliaries, western frontier.

The defence of the "golden quadrilateral" was often approached in the scientific literature, discussions usually tackling it along with the Dacian western frontier issue. 
However, information available to date is either insufficient or unclear, precisely for the sector comprised between the forts at Micia and Bologa, namely the Apuseni Mountains area ${ }^{1}$.

We consider herein a few elements of a possible functional defence model of the gold mines area. Nonetheless, we do not attempt a detailed analysis of the entire matter.

Legion's XIII Gemina quartering at Apulum as early as the first years of the province, which lasted over its entire duration, was also related to the defence of the gold area, respectively the transportation protection of the gold mined in the Apuseni Mountains area ${ }^{2}$. Epigraphic records on the legion within the mining area concentrate in Ampelum area, where epitaphs belonging to soldiers and veterans were identified ${ }^{3}$. Other two monuments dedicated by legion centurions were found at Micia ${ }^{4}$. Distribution of the bricks and tiles stamp belonging to the legion was extremely large within the province territory, records being linked to the building material circulation or the effective involvement of vexillationes in various constructional activities ("Bauvexillationen") 5 . A brick or tile stamp records in certain sites do not suppose, however, the effective presence of the legion in respective area. The interpretation of these artefacts has generated various views from one case to another ${ }^{6}$.

Except for the fortlet at $\mathrm{Abrud}^{7}$, no other fortlets in the area of the "gold quadrilateral" are known. Data registered upon the fortification sondage are scarce, only sizes and the rather inconsistent archaeological deposition level being known, accounting for a short-lived base. Epigraphic data indicate that, most likely, a vexillatio of XIII Gemina legion and, subsequently, numerus Maurorum Hispaniensium ${ }^{8}$ were stationed at Ampelum, yet the unit fort is still unidentified. It is possible that the latter serviced the procurator aurariarium based there.

Until the second half of the 2nd c. AD, there is little evidence that would define the defence of the area. It is certain that XIII Gemina legion was located under Trajan at Apulum. Overall, the state of research concerning displacement of auxiliary units to the forts in Dacia under Trajan is unsatisfactory, being often based on mere assumptions ${ }^{9}$. However, the troops dispatch picture near the "gold quadrilateral", respectively the western frontier, changes significantly under his successor.

As mentioned above, the Romanian scientific literature relates the defence of the gold area almost exclusively to XIII Gemina legion, epigraphic and archaeological evidence being those listed above. Moreover, identification of defensive structures on Dacian western frontier, between Bologa and Micia, respectively clarification of the sector defence fashion are still matters of debate. It is obvious that discussions on the defence of a certain area led par excellence to repertoires of fortifications that would form a defensive system. The results of

\footnotetext{
${ }^{1}$ Recent bibliography Nemeth 2005, Nemeth 2005a, Nemeth 2007.

${ }^{2}$ See discussions in Moga 1985, Țentea 2003, Ionescu, Ghergari, Țentea 2006.

${ }^{3}$ IDR III/3 344, 354 (soldiers), 360, 369 (veterans).

${ }^{4}$ IDR III/3 96, 115.

${ }^{5}$ Moga 1985; Piso 2000; T⿱丷entea 2003.

${ }^{6}$ See the interpretation of finds coming from bath complexes E1 and E2 at Alburnus Maior (Țentea 2003; Ionescu, Ghergari, Țentea 2006).

${ }^{7}$ Moga, Mesaroşiu 1981, 141-149; Gudea 1997, no. 20. Closest analogies in Dacia - upon fortification sizes - are Boița (Lupu 1961, 411-422; Gudea 1997, no. 46), Săpata de Jos (Tudor 1978, 298-299; Gudea 1997, no. 59), and in Moesia Superior, the small fortifications in the Porțile de Fier area (Gudea 2001, no. 11a-c, 12a-j). For small-sized fortifications in Barboşi area, see Țentea, Oltean 2009, 1515-1524. For a repertoire of such fortifications in Germania and Raetia, see Schönberger 1985, 490-493. Such small fortifications (fortlets) were signalled in Britannia starting with the immediate period after the conquest and until during the 4th c. AD. Earliest example is at Martinhoe, where the detachment based there, was most likely commissioned with the control the Channel. In the 2nd C CE, a few small fortifications of the type were built in south Scotland during Antoninus Pius rule, for instance Barburgh Mill, its two barracks being able to accommodate also a centuria.

${ }^{8}$ Petolescu 2002, 137-138.

${ }^{9}$ Matei-Popescu, Țentea 2006, 127-140.
} 
detailed studies of the Roman defensive system from southwest Dacia could not, however, resolve this aspect as well. On the frontier in Banat area, E. Nemeth provided analogies with frontier areas from east Africa ${ }^{10}$. In the intra-Carpathian area case, defence must be understood as depending on available data rather than analogies. The defensive system that the Romans envisaged in Dacia is based on a network of forts located inside the Carpathian arch, sited without exception in passes or river interflow areas. The specificity of the Dacian western frontier in the mountain area is due to the mining area, therefore in our view its defence was accomplished within a joint process.

I. Places where gold mines were exploited were connected by a road network to the military centres inside the province and the western frontier area:

The road Apulum-Ampelum-Alburnus Maior was named the road to Dacia's gold. It has a rather difficult route, especially to the end, where its field layout raises detail issues ${ }^{11}$. In case a connection road between Alburnus Maior and the small fortification at Abrud ${ }^{12}$ existed, it must have rather been a branch of Ampelum - Alburnus Maior route. Respective Roman road is less likely to have run from Ampelum - Abrud - Alburnus Maior since communication networks were not "plotted" so to join all fortifications in the area, but rather to connect most important places on short route, given the slope preservation within admitted limits.

A secondary road is signalled between Germisara - Ampelum ${ }^{13}$, connecting Mureş valley to Apuseni Mountains.

Another road ran from Micia to Ampelum. Thus, starting from Micia northwards, a possible road might have been noticed on an Austrian map drawn in the 19th C, on ŞoimuşBrad route ${ }^{14}$. Notable finds related to quarries were identified along the road linking Micia to Ampelum, in Brad area (beside numerous artifacts found randomly in the area of the current city, as well as the cemetery in the Ruda-Brad area $)^{15}$, Crişcior ${ }^{16}$ or Buceş ${ }^{17}$ areas. We should also mention the hoard composed of 23 coins found at Valea Arsului (Crişcior commune), collected between 87 and $164 \mathrm{AD}$ and deposited following the 170 - attacks on the province ${ }^{18}$.

To what extent may a road on Crişul Alb valley be identified? Visible traces of gold washery were signalled along Crişul Alb river, in Baia de Criş area ${ }^{19}$.

The Roman road on Arieş valley: Potaissa-Alburnus Maior is signalled on Arieş valley to Câmpeni, then southwards ${ }^{20}$.

V. Wollmann and Fl. Fodorean mention G. Téglás's supposition concerning certain connection roads between Mid Arieş river and western and northern areas of the limes - through a road crossing Muntele Mare to Napoca and another crossing Călineasa Mountains, reaching Crişul Repede valley at Bologa ${ }^{21}$.

\footnotetext{
${ }^{10}$ Nemeth 2005, 184. See recently Visy 2009, 115-126.

${ }^{11}$ Wollmann 1996, 70-71, pl. LXVI; Fodorean 2006, 252-254.

${ }^{12}$ Moga, Mesaroşiu 1981, 141-149.

${ }^{13}$ Fodorean 2006, 255-263.

${ }^{14}$ Fodorean 2006, 262 fig. 3.47, 263.

${ }^{15}$ Christescu 1929, 12; TIR L 34, p. 32, 79; IDR III/3 345-348; Rişcuța 1996, 280-284; Rusu 1993, 291-293; Rusu 1994, 137-152.

${ }^{16}$ TIR L35, p. 50; Bucureşci, com. Crişcior - TIR, p. 42; Rişcuţa 1996, 282.

${ }^{17}$ TIR, p. 106; Rișcuța 1996, 282, 284.

${ }^{18}$ Palamariu 1991, 667-670 (Vespasian - 2, Traian - 7, Hadrian - 5, Antoninus Pius - 6, Marcus Aurelius - 3).

${ }^{19}$ Baia de Criş (TIR L34, p. 32; Rişcuța 1996, 280); Ribița (TIR L 34, p. 96; Rişcuța 1996, 279-280); Caraci (TIR L 34, p. 44; Rişcuța 1996, 282); Țebea (TIR L 34, p. 110; Rişcuța 1996, 284).

${ }^{20}$ Fodorean 2006, 163-167. It is possible this road had a southern branch even after its exit from Lupşa: from the point named "Hărădău" (Pârâul Rălii) come several tile material fragments indicating Roman vestiges (bricks, tegulae and tegulae mammatae, with the collection of the Museum from Lupşa - see Țentea 2003, 257-258, note 40. ${ }^{21}$ Wollmann 1996, 71; Fodorean 2006, 254.
} 
II. Hence, these roads might have been easily used by troops based near the gold area, also for the transit of same or other troops to the western frontier of the province.

Locating, as early as Hadrian's rule, the single ala milliaria from Dacia at Războieni ${ }^{22}$ was not by accident. Ala I Batavorum milliaria could quickly reach both the gold area and the province west via the road on Arieş valley.

The sitting of ala Siliana in the Gilău fort must have had multiple reasons. Beside the opportunity to easily reach any area in the north of $\mathrm{Dacia}^{23}$, one should also consider the possibility that the troop could have effortlessly reached the mining area as well as certain areas of the western frontier ${ }^{24}$. We tend to believe that in emergency cases, ala Siliana could penetrate by Someş couloir very close to Bistra valley or, westwards, until the upper course of Arieş river. Access to Arieş valley was also facilitated by the passage of the Roman branch on Iara valley. Until the arrival of $\mathrm{V}$ Macedonica legion at Potaissa, it seems that this corridor was exclusively kept under the surveillance of ala I Batavorum milliaria. Troops in the Bologa fort were mainly supposed to monitor and block access from west, on the Crişul Repede river passage ${ }^{25}$.

A key pillar to the defensive system of Dacia is the fort at Micia. The fort sizes are nonspecific to auxilia forts during the Principate, which may prove that several troops were simultaneously camped there. Concerning epigraphic records, the most relevant example for the subject herein is a well-known inscription supplying that many vexillationes, belonging to auxilia and numeri, were reunited at Micia under the command of ala I Hispanorum Campagonum ${ }^{26}$ prefect. Such a force concentration was due most likely to military confrontations with barbarian populations west of $\mathrm{Dacia}^{27}$. It is hard to believe we deal with entire strength of respective troops. A constructional activity that would involve so many and various effectives is improbable. Except for the units stationed at Micia (ala I Hispanorum Campagonum, cohors II Flavia Commagenorum) are mentioned two units from Tibiscum (cohors I Vindelicorum and likely numerus Maurorum Tibiscensium), cohors I sagittariorum (Drobeta), numerus Germanicianorum from Orăşioara de Sus and ala I Batavorum milliaria (Războieni). Close connection to the troops in southwest province is noticeable, especially with Tibiscum, then with mid Mureş river, numerus Germanicianorum exploratorum (Orăştioara de Sus) and especially with ala I Batavorum milliaria (Războieni). Effectives forming numerus singularium Britannicianorum $^{28}$ (Cigmău) and numerus Maurorum Hispaniensium (Ampelum) remained probably in their own garrison. Data supplied by this inscription prove that the mobility of equestrian auxiliaries fulfilled a special function in the defensive strategy of the area.

Concerning Ampelum, we mention that except for records of XIII Gemina legion soldiers, evidence on numerus Maurorum Hispaniensium is also known. According to C. C. Petolescu, the name of mauri Hispanienses is indicative for the troops' recruitment among the Moorish tribes attacking Hispania under Marcus Aurelius (SHA, Vita Marci, 21, 1). The unit might have arrived at Ampelum to participate in the Marcomannic wars (or even under Septimius Severus ${ }^{29}$, epigraphic records on the troop being thus, of later date ${ }^{30}$. Furthermore,

\footnotetext{
${ }^{22}$ Bota et al. 2004, 291-300; Oltean 2007, 159, fig. 5.30.

${ }^{23}$ M. Macrea considered the unit's main duty was to guard the city of Napoca (Macrea 1969, 123).

${ }^{24}$ Isac 1997,14

${ }^{25}$ Gudea 1997a, 7-8. Cohort II Hispanorum scutata Cyrenaica equitata (Petolescu 2002, 113-114; Nemeth 2007, 207-208) was a unit with equestrian elements so its mobility might have been high. There are no epigraphic records on cohort I Aelia Gaesatorum milliaria that would point to an equestrian contingent, however this may be the case due to the weapon of choice included in the troop name (Petolescu 2002, 103-104; Nemeth 2004, 639-642).

${ }^{26}$ IDR III/3 77.

${ }^{27}$ Gostar 1968, 96.

${ }^{28}$ Petolescu 2002, 129-130.

${ }^{29}$ Petolescu 1983, 329-330; Petolescu 2002, 138.
} 
data on another point located close to the mining area, Cigmău, are rather incomplete in relation to the troop based there. The quartering here of numerus singularium Britannicianorum is also late, i.e. starting with the period 179-186, between records as vexilatio peditum singulari(um) Brittannicianorum, in the diploma of Drobeta ${ }^{31}$, respectively its first record at Cigmău as numerus singulariorum Britannicianorum ${ }^{32}$.

The Tibiscum and Micia forts also acted as headquarters, located in sensitive points on the western frontier. If required, vexillationes pertaining to several troops in the area were joined there. The case of the Porolissum fort, the most important point of the defensive system of Dacia Porolissensis is similar. Additionally, other forts within the Empire that fulfilled same functions are known. Among count Syrene, Egypt (where three troops were based), Dura Europos (between Parthia and Palmyra - including a few vexillations of several units), Apsarus, by the border with Cappadocia (five cohorts that could be sent to Albania, Iberia or Armenia) ${ }^{33}$.

The XIII Gemina legion was the key pillar in the defence of the gold area during the first part of the 2nd c. AD. The vulnerability of the defensive system in the area of the western frontier and especially in the gold mines area is underlined by the dispatch of V Macedonica legion to Potaissa ${ }^{34}$.

III. Many studies have argued that the wax tablets discovered in one of the galleries at Roşia Montană were hidden there due to the attacks of the barbarian peoples over the gold area during the Marcomannic wars ${ }^{35}$. The mentioned episode connects this space to events more familiar given numerous data provided by the classical historiography referencing the Marcomannic wars (a rather difficult period for the Empire since "all peoples, from Illyricum border to Gallia, conspired" ${ }^{36}$ ). The province territory was significantly disturbed following the military operations of the Marcomannic wars, being the attack target of peoples established nearby the frontier, like the Iazyges, the Dacians, the Burs, the Vandals and the Quadi. Significant human losses were registered subsequent their raids ${ }^{37}$. Restoration of the events from Dacia considered mainly the chronological hints in the wax tablets hidden at Alburnus Maior ${ }^{38}$, respectively a horizon of coin hoards (discovered at Apulum, Dumbrăvicioara, Barbura, Buciumi-Alba etc. $)^{39}$. The end of the conflict is recorded however, on several inscriptions. At Porolissum emperor Commodus is honoured by an inscription with epithet restitutor commerciorum $^{40}$. At Sarmizegetusa, the reconstruction of the temple of Liber Pater is epigraphically mentioned ${ }^{41}$, respectively the erection of a small temple belonging to gods Domnus and Domna, dedication placed by Caius Postumius Pansa, centurion of III Italica

\footnotetext{
${ }^{30}$ CIL III 1149 = IDR III/3 325; CIL III 1294 = IDR III/3 312; CIL III 1316 = IDR III/3 339; IDR III/3 302.

${ }^{31}$ RMD 123.

${ }^{32}$ CIL III $1396=$ IDR III/3 243. The troop is recorded at Cigmău by inscriptions and tile stamps indicating it bore this name exclusively.

${ }^{33}$ Ruscu, Ruscu 1996, 205-259.

${ }^{34}$ Doina Benea argued that V Macedonica was brought to Dacia in order to protect the salt mines during the Marcomannic wars (Benea 2007, 98).

${ }^{35}$ We shall mention here only a few of such studies: Daicoviciu, Piso 1975, 159; Moga, Benea 1979, 137; Gudea 1994, 73; Timoc 2007, 181-184.

${ }^{36}$ SHA, vita Marci 22, 1.

${ }^{37}$ Ruscu 2003, 129-130, 141. Literary sources indicate the penetration of the Iazyges in the Roman territory in recurrent incursions (Nemeth 2005, 53).

${ }^{38}$ Daicoviciu, Piso 1975, 162, argue punctually that the most difficult year for Dacia was 170, not 167 .

${ }^{39}$ Gudea 1994, 69.

${ }^{40}$ Gudea 1996, 80, 418; ILD 677; Matei-Popescu 2007, 241 n. 43.

${ }^{41}$ IDR III/2 11; Rusu-Pescaru, Alicu 2000, 52-58.
} 
legion $^{42}$. An inscription from Ampelum ${ }^{43}$ records, according to C. Timoc, resumption of the mining activity in the area, in the aftermath of Commodus Germanic war ${ }^{44}$.

An interesting date herein is year 169, when six new auxilia were raised from Moesia Superior (4) and Dalmatia (2). Two cohortes Aureliae novae and two cohortes Aureliae Dardanorum were recruited in Moesia Superior. Among, two were definitely milliariae equitatae, namely II nova (Stojnik, mining area Kosmaj) and II Dardanorum (Timacum Minus $)^{45}$. The two cohortes miliariae, located in the mining area, are representative for the mentioned case of raising six cohorts, both meant for the protection of respective mining areas as well as viae metallicae ${ }^{46}$. The recruitment of such troops was an exceptional state effort to ensure the security of the mining area, given changes to the province defensive system, limited so far to the frontier line ${ }^{47}$. The task of equites cohortales was to ensure control over the roads and stationes located along them, to escort convoys, to patrol or collect supplies or other necessary things ${ }^{48}$. In this context, the role of the recruited troops was to maintain traffic safety between the mining areas, the plunder danger being often mentioned within inscriptions. Not by chance, two cohorts among these troops were enrolled from among latrones Dardaniae! The Marcomannic wars thus increased the risk degree in these areas, and we should also mention that many prisoners deported in the Dardanian uprising aftermath worked in these mines ${ }^{49}$. Threats of the type were signalled in the summer of 169 both in the area of the Metaliferi Mountains between Dalmatia and Moesia Superior ${ }^{50}$ as well as in aurariae Dacicae ${ }^{51}$.

Recruitment in 169 of the six cohorts from Moesia Superior and Dalmatia should be regarded within the broad context of concurrent establishment of II and III Italica legions in Noricum and Pannonia ${ }^{52}$, as well as the dispatch of V Macedonica legion to Potaissa. At the same time, we should mention the recruitment of two cohorts Aureliae Dacorum ${ }^{53}$. The joint military command of Moesia Superior and Dacia Apulensis in 168 accounts for the Iazyges danger between Tisa and the Danube ${ }^{54}$.

\footnotetext{
${ }^{42}$ Fiedler, Höpken 2007, 445-446; Fiedler, Höpken forthcoming (we thank the authors as they kindly supplied the mentioned studies, one being forthcoming). On the record of legion centurions in Dacia see dedications from Apulum: Ulpius Vitalis, probably to the governor health (CIL III 7785 = IDR III/5 402), respectively Marcus Ulpius Caius, to the governor of the three Dacia, Lucius Marinus Perpetuus (dated 212/213-?215 after Piso 1993, 169-177) - CIL III $1178=$ IDR III/5 436

${ }^{43}$ IDR III/3 334.

${ }^{44}$ Timoc 2007, 182-183.

${ }^{45}$ Dušanić 1977, 237-238.

${ }^{46}$ Their dispatch in respective garrisons took in consideration the status of the troops previously based there, I Ulpia Pannoniorum equitata - 167-169 (Stojnik), respectively I Thracum equitata - 70-105 (Timacum Minus).

${ }^{47}$ Dušanić 1977, 243.

${ }^{48}$ Davies 1971, 751-763.

${ }^{49}$ Dušanić 1977, 240.

${ }^{50}$ IMS I 105, n. 8.

${ }^{51}$ Birley 1966, 167.

52 Dušanić 1991, 49. These legions being located in the mining areas from respective provinces (II Italica, near the mines from Noricum, and III Italica closeby the mines from Raetia).

${ }^{53}$ Data are known only for II Aurelia Dacorum (Petolescu 2002, 152), yet the troop number is indicative of a very possible cohors I Aurelia Dacorum.

${ }^{54}$ From the camp at Sirmium (or Singidunum) emperor Marcus Aurelius, launches an offensive, starting with the end of year 169, against the Iazyges and their allies, circumstances when the command of the Dacias and Moesia Superior is unified, as supplied by the career of M. Claudius Fronto, according to an inscription from Ulpia Traiana Sarmizegetusa: legatus Augusti pro praetore trium Daciarum et Moesiae Superioris, dedicated patrono, fortissimo duci, amplissimo praesidi (CIL III 1457 = IDR III/2, 90). In 169, 170 M. Claudius Fronto receives the command of the three Dacia and again of Moesia Superior, thus evidencing military difficulties on the two provinces borders. In this context, the inefficiency of the military and administrative organization of the province became obvious, a single legion being insufficient. Similar to the situation by the start of Hadrian's reign, another great general, M. Claudius Fronto (Piso 1993, 94-102, no. 21), is given a succession of exceptional commands. The inscription from Rome (CIL
} 
IV. As mentioned, the main duty of the Roman army units (auxilia, numeri or legionary vexillationes) dispatched in the mining areas or imperial quarries was to protect mining activities from external or brigand attacks. The prevalence of units equipped with cavalry units proves they were responsible not only for the mines security, but also for metals transportation or the supply of respective areas ${ }^{55}$. On the other hand, legionaries provided economic, administrative and technical support. They may be found in civil administration as librarii at Ampelum or as sole responsible for the mines administration at Timacum Minus. The army contributed to "call-up" and security of the forced labour used in certain Metalla. For instance, the populace recently conquered from northwest Spain or Pannonia, was forced to works in the mines. Moreover, damnati ad metalla from north Africa were guarded by soldiers ${ }^{56}$.

Mine exploitation areas under troop control were signalled at Montana. This is the single area inside Moesia Inferior where legions and auxilia vexillationes are recorded. In addition, we should mention that strategically, the region played a significant role as it was located by the junction of important roads ${ }^{57}$. In case of regio Montanensium ${ }^{58}$, it is a district under special military control, and it might have been a region under imperial administration. Regionarii recorded there might have been led by a centurio regionarius ${ }^{59}$ or even by consular beneficiaries. According to M. Speidel, these soldiers, regionarii, might have been attached to the troop based there at the time, functioning as district police ${ }^{60}$.

In northwest Spain, the army was involved in the control of economic resources ${ }^{61}$, providing if necessary labour or specialised personnel ${ }^{62}$. Cooperation between the civilians and soldiers is noticeable in votive inscriptions, datable in 163-191, placed in occasion of military festivals from Villalis (south Asturica Augusta), in the gold mines area. These inscriptions record detachments of VII Gemina and auxiliaries led by a centurion. A procurator ad metalla, imperial freedman and members of the military staff, including also beneficiarii of procurator Augusti of Asturia and Callaecia are mentioned. The said legion was based there to protect the area from Astures and Cantabri and ensure the security of the extracted gold transportation, especially in Las Médulas ${ }^{63}$.

The duties of beneficiarii consularis, respectively the stationes effectiveness were interpreted rather differently by the specialty literature, depending on their location within the Empire or the context when such matters were mentioned ${ }^{64}$. Hence, governor's authority in the province is visible precisely through police posts (stationes) maintained by legionaries in governor's service, as beneficiarii consularis. Circumstances within the Empire record the frequent location of such stationes nearby main roads or large cities on important commercial roads or imperial domains ${ }^{65}$. They are field marked especially on altars dedicated to Jupiter Optimus Maximus, dated rather accurately, also indicating the unit where the dedicators came

VI 1377 = IDRE I 10), comprising the career of the mentioned individual, seems to depict, step by step, the reorganization of Dacia in 168-169 CE.

${ }^{55}$ For an overview see a recent synthesis - Hirt 2010, 232-253.

${ }^{56}$ Dušanić 1991, 49; Dušanić 2000, 363.

${ }^{57}$ Velkov 1983, 49-51, Speidel 1984, 185-188.

${ }^{58}$ Rankov 1981, 58.

${ }^{59}$ Brélaz 2005, 264.

60 Speidel 1984, 185-186, argued that regionarii recorded at Montana were attached to cohors I Claudia Sugambrorum or the troops following it. For the history of this troop, units that succeeded at Montana and the issue of the Sugambri troops, see Matei-Popescu 2009 (especially no. 37-38).

${ }^{61}$ Alföldy 2008, 447.

${ }^{62}$ Domergue 1990, 348-351.

${ }^{63}$ Alföldy 2008, 447.

${ }^{64}$ Austin, Rankov 1995, 189-203; Ott 1995, 85-86.

${ }^{65}$ Brélaz 2005, 259. 
from. Their situation at Alburnus Maior is yet different, since the inscriptions known insofar do not mention the legion from where the beneficiarii consularis came. The list of epigraphic records issued in 1990 that comprises both votive inscriptions and epitaphs is statistically as follows: Noricum (58), Pannonia Superior (93), Pannonia Inferior (64), Dalmatia (71), Dacia (69), Moesia Superior (43), Moesia Inferior and Bosporus (51), Thracia (7) and Macedonia (3) ${ }^{66}$.

Statistic data of epigraphic records show that, from governor's officium, beneficiarii consularis were the most requested petty officers for policing matters, being in command of mentioned stationes ${ }^{67}$. The beneficiarii ensured connection between governor services and stationarii soldiers, thus accomplishing communication in the territory of imperial authority decisions ${ }^{68}$. Beneficiarii are found in mine exploitation areas or quarries pertaining to the imperial domain, where they were commissioned mainly with administrative control and monitoring ${ }^{69}$. They could also participate in the collection of duties and taxes. There are many recorded examples when beneficiarii carried out judicial tasks or performed preliminary investigations $^{70}$, the Egyptian papyri attesting them as governor representatives in legal matters ${ }^{71}$.

Recent excavations proved that on Hăbad plateau there were several buildings with stone ground works and timber elevation and roof $^{72}$. One is square and provided with an apse, while the other, of rectangular shape, accommodated bases of votive monuments in the courtyard. The research authors did not exclude the possibility that one of the buildings had been a statio. The thin material culture layer suggests short inhabitancy, datable mainly in the 2nd c AD. Conclusive analogies with Hăbad are found at Osterburken ${ }^{73}$.

V. Upon the arrival of V Macedonica legion in Dacia, segment Potaissa - Apulum includes two legions and an ala milliaria, thus denoting the necessity to strengthen the security of the gold area. The legion dispatch at Potaissa is indicative for the special interest in the reinforcement of a sensitive and very important area. Location of two legions at small distance to defend a strategically vital area is well known for certain Danubian sectors, like SingidunumViminacium, Brigetio-Aquincum or Vindobona-Carnuntum. In Dacia, such concentration of troops evidently points to the defence of the gold area and the western frontier, really disturbed during the Marcomannic wars.

As previously mentioned in the case of Moesia Superior, the 169 recruitment targeted the campaign in the following year against the Iazyges. Similar to other periods, the defence of the mining areas was Rome's priority, especially during crises.

Often, the scientific literature assigned fulfilment of these tasks to legionary effectives. Record of legionaries in mining areas rather account for their involvement in mining activities, providing necessary economic, administrative and technical support ${ }^{74}$. Hence, auxiliary units were mainly commissioned with the protection of the mining activities, transportation of the precious metals and supply of respective areas. This explains the preponderance of units equipped with cavalry units, based nearby this area, in forts located along roads facilitating

\footnotetext{
${ }^{66}$ Schallmayer et al. 1990; Wilkes 2005, 143.

${ }^{67}$ Austin, Rankov 1995, 195-204, Brélaz 2005, 258-260; Ott 1995, 120-123.

${ }^{68}$ Stationarii were recorded as road patrols of the mining district Mons Claudianus, where stationarii also preserved the name of the road monitored (Brélaz 2005, 259, note 177).

${ }^{69}$ Nelis-Clément 2000, 259-264.

${ }^{70}$ Brélaz 2005, 270, note 227.

${ }^{71}$ Nelis-Clément 2000, 227-243.

72 Cociș et al. 2003, 149, 162 fig. 4-7. The area drew attention consequent previous investigations, which led to the identification of 27 altars (Wollmann 1986, 253-295). If the result of first investigations was very productive related to the epigraphic component, not the same may be argued about the results of the field research.

${ }^{73}$ Schallmayer et al. 1990, 417-420, no. 544-547.

${ }^{74}$ Dušanić 1991, 49; Dušanić 2000, 363; Hirt 2010, 364.
} 
rapid access to important points of the mining area: Micia, Cigmău-Germisara, Ampelum, Războieni, Gilău, possibly also Bologa.

The defence of the gold mines in Dacia was related to that of the western frontier of the province. Thus, the XIII Gemina legion played a key role originally, while subsequently, it seems to have partially divided its duties with V Macedonica legion, as indicated firstly from the sitting of the latter, in crisis time, by the end of an important road corridor leading to this area, and then farther to the western frontier.

The ability of certain troops based inside the province to swiftly reach the area between the forts at Micia and Bologa might explain the lack of tangible field evidence in this area. Such assumption is clearly conditioned by the current state of research.

\section{BIBLIOGRAPHY}

Alföldy 2008 - G. Alföldy, Spain, The Cambridge Ancient History 11, The High Empire, AD 70-192, 2nd Edition, Cambridge.

Austin, Rankov 1995 - N. J. E. Austin, N. B. Rankov, Exploratio Military and Political Intelligence in the Roman World from the Second Punic War to the Battle of Adrianopole, London.

Birley 1966 - A. Birley, Marcus Aurelius. A Biography, London.

Benea 2007 - D. Benea, Cu privire la organizarea exploatării sării în Dacia romană, Meşteşugari şi artizani în Dacia romană, 91-112.

Bota et al. 2004 - E. Bota, L. Ruscu, D. Ruscu, C. Ciongradi, Cercetări arheologice în castrul Alei I Batavorum Milliaria de la Războieni-Cetate (jud. Alba), Apulum 41, 291-300.

Brélaz 2005 - C. Brélaz, La sécurité publique en Asie Mineure sous le Principat $\left(\mathrm{I}^{\mathrm{er}}-\mathrm{III}{ }^{\mathrm{ème}}\right.$ s. ap. J.-C.). Institutions municipales et institutions impériales dans l'Orient romain, SBA 32, Basel.

Christescu 1929 - V. Christescu, Viaţa economică a Daciei romane, Piteşti.

Cociş et al. 2003 - S. Cociş, A. Ursuţiu, C. Cosma, Radu Ardevan, Area Sacra de la Hăbad, Alburnus Maior I, 149-191.

Daicoviciu, Piso 1975 - H. Daicoviciu, I. Piso, Sarmizegetusa şi războaiele marcomanice, ActaMN 12, 159-163 = Sarmizegetusa et les guerres marcomanes, RRH 16, 1977, 155-159.

Domergue 1990 - C. Domergue, Les mines de la péninsule Ibérique dans l'antiquité romaine, Collection de l'École française de Rome 27, Rome.

Dušanić 1977 - S. Dušanić, Mounted Cohorts in Moesia Superior, Limes 11 Székesfehérvár, 237-246.

Dušanić 2000 - S. Dušanić, Army and Mining in Moesia Superior, Kaiser, Heer und Gesellschaft in der Römischen Kaiserzeit: Gedenkschrift für Eric Birley, Heidelberger althistorische Beiträge und epigraphische Studien (eds. G. Alföldy, B. Dobson, W. Eck), Stuttgart, 343-363.

Fiedler, Höpken 2007 - M. Fiedler, C. Höpken, Das ,gemeinschaftliche“ und das „private“ Opfer. Beispiele aus dem Spektrum von Votivpraktiken in römischen Heiligtümern, dargestellt an Befunden aus Apulum und Sarmizegetusa (Dakien), Kult und Kommunikation. Medien in Heiligtümern der Antike (Hrsg. Ch. Frevel, H. v. Hesberg), Zakmira-Schriften 4, Wiesbaden, 435-466.

Fiedler, Höpken forthcoming - M. Fiedler, C. Höpken, Micul templu al marilor divinități: Sanctuarul lui Domnus şi Domna din Sarmizegetusa, Studia Archaeologica et Historica in honorem Magistri Dorin Alicu, Cluj-Napoca (eds. V. Rusu-Bolindeț, T. Sălăgean, R. Varga), Cluj-Napoca.

Fodorean 2006 - F. Fodorean, Drumurile din Dacia romană, Cluj-Napoca.

Gostar 1968 - N. Gostar, O stare de alarmă pe limesul de vest al Daciei, AUI 14, 93-102.

Gudea 1994 - N. Gudea, Dacia Porolissensis und die Markomannenkriege, Markomannenkriege. Ursachen und Wirkungen. Brno Spisy Archaeologičkho Ustavu Au. CR 1, 371-86, 371-386 = Dacia Porolissensis în timpul războaielor marcomanice, ActaMP 18, 67-93. 
Gudea 1996 - N. Gudea, Porolissum. Un complex daco-roman la marginea de nord a Imperiului Roman. II. Vama romană. Monografie arheologică. Contribuții la cunoaşterea sistemului vamal din provinciile dacice, Cluj-Napoca.

Gudea 1997 - N. Gudea, Der dakische Limes. Materialien zu seiner Geschichte, JRGZM 44 (Sonderdruck), 1-114.

Gudea 1997a - N. Gudea, Das Römergrenzkastell von Bologa-Resculum, Zalău.

Gudea 2001 - N. Gudea, Die Nordgrenze der römischen Provinz Obermoesien. Materialien zu ihrer Geschichte (86-275 n. Ch.), JRGZM 48 (Sonderdruck), 1-118.

Hirt 2010 - A. M. Hirt, Mines and quarries in the Roman Empire: Organizational aspects 27 BC - AD 235, Oxford.

Ionescu, Ghergari, Țentea 2006 - C. Ionescu, L. Gherghari, O. Țentea, Interdisciplinary (mineralogicalgeological-archaeological) study on the tegular material belonging to the Legion XIII Gemina from Alburnus Maior (Roşia Montană) and Apulum (Alba Iulia): possible raw materials sources, CA 13, 413-436.

Isac 1997 - D. Isac, Castrele de cohortă şi ală de la Gilău/ Die Kohorten - und Alenkastelle von Gilău, Zalău. Lupu 1961 - N. Lupu, Săpăturile de la Boița, MCA 7, 411-422.

Macrea 1969 - M. Macrea, Viaţa in Dacia romană, Bucureşti.

Matei-Popescu 2007 - F. Matei-Popescu, Despre originea negustorilor din provincia Dacia pe baza analizei surselor epigrafice. Stadiul problemei, Meşteşuguri şi artizani în Dacia romană, 235-246.

Matei-Popescu 2009 - F. Matei-Popescu, The Roman Army in Moesia Inferior, Bucharest.

Matei-Popescu, T,entea 2006 - F. Matei-Popescu, O. T,entea, The Participation of Upper Moesian Auxiliary Units to the Trajans Dacian Wars, Dacia N.S. 50, 127-140.

Moga, Benea 1979 - M. Moga, Doina Benea, Tibiscum în lumina izvoarelor epigrafice, Tibiscus 5 , 141148.

Moga 1985 - V. Moga, Din istoria militară a Daciei romane. Legiunea XIII Gemina, Cluj-Napoca.

Moga, Mesaroşiu 1981 - V. Moga, V. Mesaroşiu, Cercetări arheologice de la Abrud, Apulum 18, 141-149.

Nelis-Clément 2000 - J. Nelis-Clément, Les Beneficiarii: Militaires et administrateurs au service de l'Empire (Ier s. a.C.-VIe s. p.C.), Bordeaux.

Nemeth 2004 - E. Nemeth, Cohors I Aelia Gaesatorum milliaria. Die Identität einer römischen Hilfstruppen, Orbis antiquus, 639-642.

Nemeth 2005 - E. Nemeth, Armata în sud-vestul Daciei romane / Die Armee in Südwesten des römischen Dakien), Timişoara.

Nemeth 2005a - E. Nemeth, Die römischen Befestigungen im Westen Rumäniens, Limes Dacicus Occidentalis. Die Befestigungen im Westen Dakiens vor und nach der römischen Eroberung (eds. E. Nemeth, A. Rustoiu, H. Pop), Cluj-Napoca, 78-100.

Nemeth 2007 - E. Nemeth, Politische und militärische Beziehungen zwischen Pannonien und Dakien in der Römerzeit / Relaţii politice şi militare între Pannonia şi Dacia în epoca romană, Cluj-Napoca.

Oltean 2007 - I. A. Oltean, Dacia. Landscape, colonization, romanization, London - New York.

Ott 1995 - J. Ott, Die Beneficiarier. Untersuchungen zu ihrer Stellung innerhalb der Rangordnung des römischen Heeres und zu ihrer Funktion, Historia 92, Stuttgart.

Palamariu 1991 - O. Palamariu, Tezaurul de denari imperiali de la Valea Arsului - Brad, Sargetia 2124, 1988-1991, 667-670.

Petolescu 1983 - C. C. Petolescu, Numerus Maurorum Hisp., Gerion 1, 327-330.

Petolescu 2002 - C. C. Petolescu, Auxilia Daciae. Contribuție la istoria militară a Daciei romane, Bucureşti.

Piso 1993 - I. Piso, Fasti Provinciae Daciae, Bonn.

Piso 2000 - I. Piso, Les légions dans la province de Dacie, Les légions de Rome sous le Haut-Empire. Actes du Congrès de Lyon (17-19 septembre 1998) (ed. Y. Le Bohec), Lyon.

Rankov 1981 - B. Rankov, A Contribution to the Military and Administrative History of Montana, Ancient Bulgaria. Papers presented to the International Symposium on the Ancient History and Archaeology of Bulgaria, University of Nottingham (ed. A. G. Poulter), Part 2, Nottingham 1983, p. 4073, esp. 49-51.

Rişcuța 1995-1996 - C. Rişcuța, Repertoriul arheologic al depresiunii Brad, Sargetia 26, 1, 265 -317. 
Ruscu 2003 - Dan Ruscu, Provincia Dacia în istoriografia antică, Cluj-Napoca.

Rusu 1993 - A. Rusu, Necropola romană de la Muncelu-Brad, MCA 13, 291-293.

Rusu 1994 - Adriana Rusu, Les Illyriens en Dacie, Sargetia 25, 1992-1994, 137-152.

Rusu-Pescaru, Alicu 2000 - A. Rusu-Pescaru, D. Alicu, Templele romane din Dacia 1, Deva.

Schallmeyer 1990 - E. Schallmeyer et al., Der römische Weihebezirk von Osterburken I: Corpus der griechischen und lateinischen Beneficiarier-Inschriften des römischen Reiches, Stuttgart.

Schönberger 1985 - H. Schönberger, Die römischen Truppenlager der frührn und mitlleren Kaiserzeit zwischen Nordsee und Inn, BerRGK 66, 321-497.

SHA - Scriptores Historiae Augustae, Cambridge MA (Loeb 139).

Speidel 1984 - M.P. Speidel, Regionarii in Lower Moesia, ZPE 57, 185-188.

Timoc 2007 - C. Timoc, Ampelum şi războaiele marcomanice, Apulum 44, 1, 181-184

Tudor 1978 - D. Tudor, Oltenia romană (ed. 4), Bucureşti.

Țentea 2003 - O. Țentea, Legion XIII Gemina and Alburnus Maior, Apulum 40, 253-265.

Țentea, Oltean 2009 - O. Țentea, I. A. Oltean, The Lower Danube Roman Limes at Galați (Romania). Recent results from excavation and aerial photographic interpretation, Limes 20 León, 1515-1523.

Velkov 1983 - V. Velkov, Roman Cities in Bulgaria. Collected Studies, Amsterdam.

Visy 2009 - Zs. Visy, Mapping the SW Limes of Dacia, The Army and Frontiers of Rome (Papers offered to David J. Breeze on the occasion of his sixty-fifth birthday and his retirement from Historic Scotland (ed. W. S. Hanson), JRA Suppl. Ser. 74, 115-126.

Wilkes 2005 - J. J. Wilkes, The Roman Danube: An Archaeological Survey, JRS 95, 124-225.

Wollmann 1996 - V. Wollmann, Mineritul metalifer, extragerea sării şi carierele de piatră în Dacia romană. Der Erzbergbau, die Salzgewinnung und die Steinbrüche im römischen Dakien. Bibliotheca Musei Napocensis 13, Cluj-Napoca. 